\title{
IMPLIKASI YURIDIS PERJANJIAN PERKAWINAN YANG DIBUAT SELAMA DALAM IKATAN PERKAWINAN TERHADAP UTANG BERSAMA PASCA PUTUSAN MAHKAMAH KONSTITUSI NOMOR 69/PUU-XIII/2015
}

\author{
Priesty Yustika Putri, Prija Djatmika, Dhiana Puspitawati \\ Magister Kenotariatan, Pacasarjana Unversitas Brawijaya Malang \\ Jalan Veteran Malang, Jawa Timur \\ Email : priestyyustika92@gmail.com
}

\begin{abstract}
Under the provisions of Article 29 of Law Number 1 Year 1974 on Marriage, a marriage agreement may only be made before or at the time of marriage. However, after the Decision of the Constitutional Court Number 69/PUU-XIII/2015, marriage agreements may also be made during the period of marriage ties. The making of this marriage agreement certainly affects the joint property of husband and wife obtained in the marriage period before the marriage agreement is made. Including if the couple also has a debt together. This then raises problems related to debt settlement. The purpose of this study is to determine the juridical implications of marriage agreements made during the marriage bonds to the joint debt post-Decision of the Constitutional Court. This research is classified as normative juridical research using the concept of law and conceptual. The results of the study show that after the Decision of the Constitutional Court Number 69/PUU-XIII/2015, which stipulates that a marriage agreement may be made during the period of marriage bonds related to the responsibility of the joint debt repayment arising prior to the marriage agreement, the settlement may be contracted as per the second agreement the husband and wife. This is because there are no rules that prohibit the existence of such clauses to be set forth in the marriage agreement. However, if a marriage agreement in which the settlement of the joint debt will result in harm to a third party then the marriage agreement is not allowed, as regulated in Article 29 paragraph (4) Act 1/1974.
\end{abstract}

Keywords: Marriage Agreement, Joint Debt, Constitutional Court Decision.

\begin{abstract}
Abstrak
Berdasarkan ketentuan dalam Pasal 29 Undang-Undang Nomor 1 Tahun 1974 Tentang Perkawinan, perjanjian perkawinan hanya dapat dibuat sebelum atau pada saat perkawinan berlangsung. Akan tetapi, pasca Putusan Mahkamah Konstitusi Nomor 69/PUU-XIII/2015, perjanjian perkawinan juga dapat dibuat selama dalam masa ikatan perkawinan. Pembuatan perjanjian perkawinan ini tentu berpengaruh terhadap harta bersama suami istri yang diperoleh dalam masa perkawinan sebelum dibuatnya perjanjian perkawinan. Termasuk apabila pasangan suami istri tersebut juga memiliki utang bersama. Hal ini kemudian menimbulkan permasalahan yang berkaitan dengan penyelesaian utang tersebut.Tujuan penelitian ini adalah untuk mengetahui implikasi yuridis perjanjian perkawinan yang dibuat selama dalam ikatan perkawinan terhadap utang bersama pasca Putusan Mahkamah Konstitusi tersebut. Penelitian ini tergolong penelitian yuridis normatif yang menggunakan pendekatan undang-undang dan konseptual. Hasil penelitian menunjukan bahwa pasca
\end{abstract}


Putusan Mahkamah Konstitusi Nomor 69/PUU-XIII/2015, yang mengatur bahwa perjanjian perkawinan dapat dibuat selama dalam masa ikatan perkawinan, terkait tanggung jawab pelunasan utang bersama yang timbul sebelum adanya perjanjian perkawinan tersebut, pelunasannya dapat diperjanjikan sesuai kesepakatan kedua pihak yaitu suami dan istri. Hal ini karena tidak ada aturan yang melarang adanya klausula tersebut untuk dituangkan dalam perjanjian perkawinan. Namun jika dengan adanya perjanjian perkawinan yang di dalamnya mengatur mengenai pelunasan utang bersama tersebut justru berakibat merugikan pihak ketiga maka perjanjian perkawinan itu tidak diperbolehkan, sebagaimana yang diatur dalam Pasal 29 ayat (4) UU 1/1974.

\section{Kata kunci: Perjanjian perkawinan, Utang Bersama, Putusan Mahkamah Konstitusi.}

\section{A. PENDAHULUAN}

Manusia sebagai makhluk sosial memiliki naluri untuk berinteraksi dan hidup bersama dengan sesamanya. Naluri tersebut menimbulkan dorongan dalam diri setiap manusia untuk hidup bersama, yang diwujudkan dalam bentuk perkawinan. Sudah menjadi kodrat alam dua orang manusia dengan jenis kelamin yang berlainan, yaitu seorang laki-laki dan seorang perempuan ada daya saling tarik-menarik satu sama lainnya untuk hidup bersama. ${ }^{1}$ Perkawinan merupakan satu-satunya bentuk kehidupan bersama antara dua individu yaitu laki-laki dan perempuan yang diakui secara sah oleh Negara dan dilindungi oleh hukum yang berlaku, sebagaimana dikatakan oleh Paul Scholten bahwa "Perkawinan adalah hubungan pria dan wanita untuk hidup bersama yang mana hubungan itu bersifat kekal dan diakui negara." 2

Peraturan tentang perkawinan itu sendiri di Indonesia diatur dalam UndangUndang Nomor 1 Tahun 1974 tentang Perkawinan (atau yang selanjutnya disebut UU 1/1974), dimana dalam pasal 1 mendefinisikan Perkawinan ialah ikatan lahir batin antara seorang pria dengan seorang wanita sebagai suami istri yang bertujuan membentuk keluarga (rumah tangga) yang bahagia dan kekal yang berdasarkan Ketuhanan Yang Maha Esa." Berdasarkan definisi perkawinan dalam UU 1/1974, dapat disimpulkan bahwa perkawinan adalah ikatan antara laki-laki dan perempuan yang mana ikatan tersebut tidak hanya sekedar ikatan jasmani saja, melainkan juga termasuk ikatan rohani di dalamnya. Disini ikatan rohani menurut UU 1/1974 juga berperan penting terhadap pembentukan keluarga (rumah tangga) yang bahagia dan kekal.

Berbeda dengan Kitab Undang-Undang Hukum Perdata Indonesia (atau yang selanjutnya disebut dengan KUH Perdata), menurut KUH Perdata perkawinan hanyalah sebatas ikatan keperdataan saja. Hal tersebut dapat dilihat pada Pasal 26 KUH Perdata yang menyatakan "Undang-undang memandang soal perkawinan hanya dalam hubunganhubungan perdata". Berdasarkan hal tersebut, maka diketahui bahwa KUH Perdata

\footnotetext{
${ }^{1}$ Wirjono Prodjodikoro, (1981), Hukum Perkawinan di Indonesia, Cet. Keenam, Bandung: Sumur Bandung, hlm. 7.

${ }^{2}$ R. Soetojo Prawirohamidjojo dan Asis Safioedin, (1985), Hukum Orang dan Keluarga, Bandung: Alumni, hlm. 31.
} 
mengesampingkan urusan kerohanian dan hal tersebut dianggap tidak penting selama tidak diatur dalam hubungan hukum perdata. ${ }^{3}$

Perkawinan sebagai lembaga hukum, mempunyai akibat yang penting dalam kehidupan para pihak yang melangsungkan perkawinan. ${ }^{4}$ Akibat hukum yang timbul dibagi menjadi dua kelompok, yang pertama akibat hukum terhadap individu atau diri pribadi suami istri itu sendiri, dan yang kedua adalah akibat kebendaan yaitu akibatakibat hukum terhadap harta kekayaan suami istri tersebut, baik yang sudah ada maupun yang akan diperoleh selama perkawinan berlangsung. Pengaturan mengenai harta benda dalam perkawinan diatur di dalam Pasal 35, Pasal 36 dan Pasal 37 UU 1/1974. Adapun bunyi dari pasal-pasal tersebut adalah sebagai berikut:

1. Pasal 35

(1) Harta benda yang didapat selama masa perkawinan menjadi harta bersama.

(2) Harta bawaan dari masing-masing suami dan istri dan harta benda yang diperoleh masing-masing sebagai hadiah atau warisan, adalah di bawah penguasaan masing-masing sepanjang para pihak tidak menentukan lain.

2. Pasal 36

(1) Mengenai harta bersama suami atau istri dapat bertindak atas perjanjian kedua belah pihak.

(2) Mengenai harta bawaan masing-masing, suami dan istri mempunyai hak sepenuhnya untuk melakukan perbuatan hukum mengenai harta bendanya.

3. Pasal 37

(1) Bila perkawinan putus karena perceraian, harta bersama diatur menurut hukum masing-masing.

Berdasarkan ketentuan dalam pasal-pasal di atas, harta benda dalam perkawinan dibagi menjadi dua, yaitu:

1. Harta bawaan suami atau istri

Yang dimaksud dengan harta bawaan adalah harta bawaan dari masingmasing suami dan istri dan harta benda yang diperoleh masing-masing sebagai hadiah atau warisan. ${ }^{5}$

Terkait dengan harta bawaan, UU 1/1974 juga mengatur bahwa setelah adanya perkawinan, suami istri tetap memiliki hak sepenuhnya untuk melakukan perbuatan hukum mengenai harta bendanya tersebut tanpa memerlukan persetujuan dari suami atau istri.

2. Harta bersama

\footnotetext{
${ }^{3}$ Khomariah, (2004), Hukum Perdata, Malang,: UMM Press, hlm. 38.

${ }^{4}$ J. Satrio, (1993), Hukum Harta Perkawinan, Bandung: Citra Aditya Bhakti, hlm. 28.

${ }^{5}$ Khomariah, op.cit. hlm. 53
} 
Harta bersama adalah harta benda yang diperoleh selama ikatan perkawinan kecuali yang diperoleh karena hibah atau warisan. ${ }^{6}$ Dalam penguasaan dan pengurusan harta bersama ini, baik suami maupun istri harus bertindak atas persetujuan kedua belah pihak.

Akan tetapi sekalipun telah diatur dengan jelas dalam UU 1/1974, dalam prakteknya masih saja sering terjadi permasalahan terkait dengan pengurusan harta bersama tersebut dan dapat menimbulkan perselisihan antara suami dan istri. Terlebih lagi jika sampai terjadi putusnya perkawinan atau perceraian, tidak jarang persoalan harta bersama ini menjadi permasalahan yang rumit dan sangat sulit untuk diselesaikan.

Sehingga untuk menghindari hal-hal tersebut yang kemungkinan dapat timbul di kemudian hari, peraturan dalam UU 1/1974 yang mengatur tentang harta benda dalam perkawinan khususnya tentang harta bersama dapat disimpangi dengan jalan membuat suatu kesepakatan bersama antar suami dan istri sebelum dilangsungkannya perkawinan. Pasal 36 UU 1/1974 memberikan kesempatan bagi pasangan suami istri apabila mereka memutuskan dan sepakat untuk menetukan lain terkait dengan harta bersama dalam perkawinan, atau dengan kata lain mengadakan penyimpangan dari ketentuan yang ada selama tidak bertentangan dengan hukum, agama, dan kesusilaan. Kesepakatan tersebut biasanya dituangkan dalam bentuk perjanjian tertulis yang disebut perjanjian perkawinan.

Perjanjian perkawinan dalam arti formal adalah tiap perjanjian yang dilangsungkan sesuai dengan ketentuan undang-undang antara calon suami istri mengenai perkawinan mereka, dan tidak dipermasalahkan apapun isinya. ${ }^{7}$ Selain itu, perjanjian perkawinan juga merupakan cara untuk menyimpangi peraturan yang mengatur tentang harta benda dalam perkawinan, pada saat atau sebelum perkawinan berlangsung, calon suami dan calon istri berdasarkan kesepakatan bersama dapat membuat perjanjian secara tertulis yang selanjutnya disahkan oleh Pegawai Pencatat Perkawinan, yang isinya berlaku juga bagi pihak ketiga. ${ }^{8}$ Dengan kata lain, dapat disimpulkan bahwa perjanjian perkawinan adalah suatu perjanjian yang dibuat oleh calon suami atau istri secara tertulis yang menyatakan bahwa mereka telah saling setuju dan mufakat untuk membuat pemisahan atas harta benda mereka masing-masing dalam perkawinan, dimana dengan ditandatanganinya perjanjian perkawinan tersebut maka semua harta mereka, baik harta yang mereka bawa sebelum mereka menikah maupun harta yang mereka peroleh setelah mereka menikah akan tetap menjadi milik mereka masing-masing. Demikian juga halnya dengan utang dari masing-masing pihak, akan tetap menjadi tanggung jawab dari pihak yang memiliki utang tersebut. ${ }^{9}$

\footnotetext{
${ }^{6}$ Khomariah, loc.cit.

${ }^{7}$ H.A. Damanhuri HR, (2007), Segi-Segi Hukum Perjanjian Perkawinan Harta Bersama, Bandung: Mandar Maju, hlm. 1.

${ }^{8}$ Wahyono Darmabrata, (2008), Tinjauan Undang-Undang No. 1 Tahun 1974 Tentang Perkawinan beserta Undang-Undang dan Peraturan Pelaksanaannya, Jakarta: Rizkita, hlm. 22.

${ }^{9}$ Annisa Istrianty, (2015), Akibat Hukum Perjanjian Perkawinan Yang dibuat Setelah Perkawinan Berlangsung, Privat Law, Volume 3, Surakarta: Fakultas Hukum Universitas Sebelas Maret, hlm. 85.
} 
Perjanjian perkawinan bukanlah perjanjian yang dibuat dalam rangka perceraian. Meski banyak anggapan di masyarakat apabila ada pasangan yang hendak melangsungkan perkawinan kemudian memutuskan untuk membuat perjanjian perkawinan, maka mereka mempersiapkan untuk perceraiannya. Terlepas dari anggapan negatif masyarakat tentang perjanjian perkawinan, ada nilai-nilai positif dibalik maksud dibuatnya perjanjian perkawinan tersebut, yaitu untuk memberikan perlindungan bagi suami istri yang akan terikat dalam suatu perkawinan.

Sebagai contoh adalah, perjanjian perkawinan yang dibuat oleh pasangan yang berasal dari dunia bisnis, dimana salah satu pihak memiliki bidang usaha yang beresiko tinggi yang ada kalanya dapat mengalami kemunduran karena sangat tergantung pada situasi perekonomian. Apabila salah satu pihak ingin mengajukan kredit pada bank dengan jaminan harta yang dimilikinya, maka utang yang akan timbul setelahnya hanya akan mengikat pihak yang terkait saja, sedangkan pasangannya akan terbebas dari kewajiban dan resiko pembayaran utang. Kemudian apabila debitur dinyatakan bangkrut maka harta kekayaannya saja yang akan disita oleh kreditur, sementara harta pasangannya tidak. Dengan demikian keluarganya masih bisa menjalankan kehidupan sehari-hari terutama menjamin kesejahteraan kedua belah pihak dan anak-anak dengan menggunakan harta yang dimiliki pasangannya sehingga tidak ada pihak lain yang dirugikan dalam hal ini. Pemahaman yang sesungguhnya mengenai perjanjian kawin akan merubah pandangan masyarakat mengenai pasangan yang membuat perjanjian kawin sebelum melangsungkan perkawinan dan memberikan kepastian bagi tiap pasangan dalam menjalankan bahtera rumah tangga.

Perihal perjanjian perkawinan diatur di dalam Pasal 29 UU 1/1974. Adapun ketentuan dari pasal tersebut adalah sebagai berikut:

1. Pada waktu atau sebelum perkawinan dilangsungkan, kedua pihak atas persetujuan bersama dapat mengadakan perjanjian tertulis yang disahkan oleh Pegawai Pencatat Perkawinan, setelah mana isinya berlaku juga terhadap pihak ketiga sepanjang pihak ketiga tersangkut.

2. Perjanjian tersebut tidak dapat disahkan bilamana melanggar batas hukum, agama dan kesusilaan.

3. Perjanjian tersebut berlangsung semenjak perkawinan dilangsungkan.

4. Selama perkawinan berlangsung perjanjian tersebut tidak dapat diubah, kecuali bilamana dari kedua belah pihak ada persetujuan untuk mengubah dan perubahan tidak merugikan pihak ketiga.

Pasal 29 UU /1974 di atas adalah salah satu pasal yang bersifat pelaksanaan, yang merupakan dasar hukum kebolehan bagi calon suami istri untuk mengadakan perjanjian perkawinan, sebab masalah harta benda dalam perkawinan telah diatur oleh sistem hukum sebelumnya, yakni menurut pola hukum yang ada berdasarkan pemisahan harta, dimana semua harta kekayaan pribadi dari suami maupun istri berada dibawah 
penguasaan masing-masing. ${ }^{10}$ Sehingga pada intinya Pasal 29 UU 1/1974 hanya mengatur bahwa: ${ }^{11}$

1. Perjanjian perkawinan dapat diadakan pada waktu atau sebelum perkawinan dilangsungkan;

2. Perjanjian perkawinan harus tertulis, yang disahkan oleh Pegawai Pencatat Perkawinan;

3. Perjanjian tidak boleh melanggar batas-batas hukum, agama, dan kesusilaan;

4. Perjanjian perkawinan berlaku terhadap pihak ketiga setelah perjanjian tersebut disahkan oleh Pegawai Pencatat Perkawinan. Sedang berlaku terhadap kedua belah pihak, sejak perkawinan tersebut dilangsungkan;

5. Selama perkawinan berlangsung, perjanjian tersebut tidak dapat diubah, kecuali bila dari kedua belah pihak ada persetujuan untuk mengubah dan perubahan tidak merugikan pihak ketiga.

Jika suatu perkawinan dilangsungkan tanpa adanya perjanjian perkawinan, maka sesuai dengan ketentuan dalam UU 1/1974 harta yang diperoleh setelah perkawinan menjadi harta bersama, sehingga utang-utang yang timbul setelah dilangsungkannya perkawinan tersebut juga menjadi tanggung jawab bersama antara suami dan istri. Sedangkan apabila sebelum melangsungkan perkawinan pasangan calon suami istri sepakat untuk membuat perjanjian perkawinan terlebih dahulu, maka semua harta mereka baik harta yang mereka bawa sebelum menikah maupun harta yang mereka peroleh setelah menikah akan tetap menjadi milik mereka masing-masing. Demikian juga halnya dengan utang dari masing-masing pihak, akan tetap menjadi tanggung jawab dari pihak yang memiliki utang tersebut.

Pada tanggal 27 Oktober 2016, Mahkamah Konstitusi mengeluarkan Putusan Nomor 69/PUU-XIII/2015 (atau yang selanjutnya disebut PMK 69/2015), dimana putusan tersebut telah merubah dan menambah norma pengaturan perjanjian perkawinan yang sebelumnya diatur dalam Pasal 29 UU 1/1974. Adapun perubahan dan penambahan norma tersebut adalah sebagai berikut:

a. Perjanjian perkawinan dapat dibuat sebelum, pada waktu dilangsungkan, atau selama dalam ikatan perkawinan dan dapat disahkan oleh Pegawai Pencatat Perkawinan atau oleh Notaris;

b. Perjanjian perkawinan mulai berlaku sejak perkawinan dilangsungkan, kecuali ditentukan lain dalam perjanjian perkawinan;

c. Perjanjian perkawinan dapat diubah atau dicabut dengan persetujuan para pihak sepanjang tidak merugikan pihak ketiga.

\footnotetext{
${ }^{10}$ H.A. Damanhuri HR, op.cit. hlm. 9.

${ }^{11}$ Khomariah, op.cit. hlm. 56-57.
} 
Adanya beberapa perubahan dan penambahan norma pada PMK 69/2015 menimbulkan banyak problematika hukum, khususnya terkait dengan perjanjian perkawinan yang dibuat dalam masa ikatan perkawinan. Salah satu permasalahan yang dianggap menarik yaitu tentang akibat terhadap utang piutang yang timbul setelah perkawinan berlangsung apabila pasangan suami istri memutuskan untuk membuat perjanjian perkawinan dalam masa ikatan perkawinan tersebut. Sebagaimana diatur dalam UU 1/1974, utang yang timbul setelah dilangsungkannya perkawinan merupakan tanggung jawab bersama suami istri. Sehingga dengan dikeluarkannya PMK 69/2015 ini yang membuka peluang bagi suami istri untuk membuat perjanjian perkawinan selama dalam masa ikatan perkawinan, muncul permasalahan salah satunya terkait dengan penyelesaian atas utang yang sebelumnya menjadi tanggung jawab bersama suami istri tersebut.

\section{B. RUMUSAN PERMASALAHAN}

Rumusan masalah dalam penelitian ini adalah apa implikasi yuridis perjanjian perkawinan yang dibuat selama dalam ikatan perkawinan terhadap utang bersama pasca Putusan Mahkamah Konstitusi Nomor 69/PUU-XIII/2015?

\section{METODOLOGI PENELITIAN}

Jenis penelitian ini adalah penelitian yuridis normatif (normative legal research). Penelitian ini merupakan penelitian yang menggunakan studi kepustakaan atau studi dokumen yang ditujukan pada peraturan-peraturan tertulis ataupun bahan hukum yang lain. ${ }^{12}$ Pendekatan penelitian yang digunakan di dalam penelitian ini antara lain adalah pendekatan undang-undang (statute approach) dan pendekatan konseptual (conceptual approach). Bahan hukum dari penelitian ini terdiri dari bahan hukum primer, bahan hukum sekunder dan bahan hukum tersier. Sumber bahan hukum penelitian ini didapat melalui Perpustakaan Pusat milik Universitas Brawijaya Malang, Pusat Dokumentasi dan Informasi Hukum (PDIH) milik Fakultas Hukum Universitas Brawijaya Malang. Tehnik pengumpulan bahan hukum untuk mengumpulkan bahan hukum dalam penelitian ini adalah dengan melakukan studi kepustakaan (library research), yaitu teknik yang digunakan dengan membaca, mengumpulkan, mempelajari, membuat catatan dan kutipan, serta menganalisis bahan-bahan pustaka yang berupa karya tulis dari para ahli dan peraturan perundang-undangan yang berlaku yang berkaitan dengan permasalahan yang dibahas. Tehnik analisis bahan hukum dalam penelitian ini menggunakan tehnik analisis interpretasi atau penafsiran. Adapun jenis intepretasi atau penafsiran yang digunakan adalah intepretasi gramatikal dan intepretasi sistematis.

\footnotetext{
${ }^{12}$ Bambang Waluyo, (1996), Metode Penelitian Hukum, Jakarta: Sinar Grafika, hlm. 13.
} 


\section{PEMBAHASAN}

\section{Perjanjian Perkawinan Sebelum Putusan Mahkamah Konstitusi Nomor 69/PUU- XIII/2015}

Menurut Wirjono Prodjodikoro, kata perjanjian diartikan sebagai "suatu perhubungan hukum mengenai harta benda kekayaan antara dua pihak, dalam mana satu pihak berjanji atau dianggap berjanji untuk melakukan suatu hal, sedang pihak lain berhak menuntut pelaksanaan janji itu". ${ }^{13}$ Perjanjian perkawinan pada prinsipnya sama dengan perjanjian pada umumnya, karena sama-sama terikat dengan Pasal 1320 KUH Perdata yang mengatur tentang syarat-syarat sahnya suatu perjanjian, yaitu sepakat, cakap, suatu hal tertentu, dan sebab yang halal.

Dengan demikian kata perjanjian sebagai hubungan hukum apabila dikaitkan dengan kata perkawinan, juga akan mencakup pembahasan mengenai harta benda dalam perkawinan. Harta benda yang dimaksud dalam hal ini selain harta pribadi dan harta bersama, juga meliputi utang piutang suami maupun istri.

Berdasarkan ketentuan dalam Pasal 119 KUH Perdata, harta persatuan pribadi suami istri berlaku persatuan bulat, yakni sejak perkawinan dilangsungkan, maka terjadilah percampuran antara harta kekayaan suami dan harta kekayaan istri. Keadaan yang demikian ini berlangsung seterusnya dan tidak dapat diubah selama perkawinan. Tetapi apabila pasangan suami istri tersebut ingin menyimpang dari peraturan umum tersebut, maka harus dituangkan dalam suatu perjanjian perkawinan. Perjanjian perkawinan yang dimaksud ini harus dibuat sebelum perkawinan dilangsungkan dalam bentyuk suatu akta Notaris, serta tidak dapat diubah selama perkawinan. Hal ini dikarenakan undang-undang yaitu KUH Perdata menghendaki supaya keadaan kekayaan dalam suatu perkawinan itu tetap, demi untuk melindungi kepentingan pihak ketiga.

Kemudian terkait dengan perjanjian perkawinan diatur lebih lanjut dalam Pasal 139 KUH Perdata, yang berbunyi:

"Dengan mengadakan perjanjian perkawinan, kedua calon suami istri adalah berhak menyiapkan beberapa penyimpangan dari peraturan undang-undang sekitar persatuan harta kekayaan, asal perjanjian itu tidak menyalahi tata susila yang baik atau tata tertib umum dan asal diindahkan pula segala ketentuan di bawah ini."

Dalam KUH Perdata, ketentuan mengenai perjanjian perkawinan diatur dalam 40 (empat puluh) pasal. Beberapa hal yang harus diperhatikan sebagai ketentuan umum dalam membuat perjanjian perkawinan adalah sebagai berikut: ${ }^{14}$

a. Perjanjian tidak boleh bertentangan dengan kesusilaan atau dengan ketertiban umum (Pasal 139 KUH Perdata);

\footnotetext{
${ }^{13}$ Wirjono Prodjodikoro, Op. Cit. hlm. 11.

${ }^{14}$ Hilman Hadikusuma, (1990), Hukum Perkawinan Indonesia, Bandung: Mandar Maju, hlm. 56.
} 
b. Perjanjian itu tidak boleh menyimpang dari kekuasaan yang oleh undangundang diberikan kepada suami selaku kepala rumah tangga, misalnya tidak boleh dijanjikan bahwa si istri akan mempunyai tempat kediaman sendiri, tidak turut pada suami (Pasal 140 ayat (1) KUH Perdata);

c. Dalam perjanjian itu tidak boleh melepaskan hak mereka yang diberikan undang-undang atas harta peninggalan keluarga sedarah mereka dalam garis ke bawah (Pasal 141 KUH Perdata);

d. Dalam perjanjian perkawinan tidak boleh ditentukan bahwa dalam hal ada percampuran harta, satu pihak harus membayar sebagian utang yang jumlahnya lebih besar dibandingkan bagiannya dalam laba persatuan (Pasal 142 KUH Perdata);

e. Dalam perjanjian perkawinan tidak boleh secara umum ditunjuk begitu saja kepada peraturan yang berlaku dalam suatu negara asing (Pasal $143 \mathrm{KUH}$ Perdata).

Akan tetapi, saat ini di Indonesia telah berlaku unifikasi dalam bidang hukum perkawinan, yaitu UU 1/1974 tentang Perkawinan yang mulai berlaku sejak tanggal 1 Oktober 1975 dan PP Nomor 9 Tahun 1975 yang merupakan peraturan pelaksanaannya. Dengan berlakunya UU 1/1974 tersebut maka semua peraturan hukum baik yang ada di dalam KUH Perdata maupun peraturan-peraturan lain yang mengatur tentang perkawinan sepanjang telah diatur dalam UU 1/1974 menjadi tidak berlaku lagi. Sebaliknya, ketentuan yang ada masih tetap berlaku sepanjang belum diatur dan memang ditunjuk masih berlaku oleh UU 1/1974 dan tidak bertentangan dengan ketentuan yang ada dalam UU 1/1974 itu sendiri. Hal ini sebagaimana yang diatur dalam Pasal 66 UU 1/1974, dimana menurut Prof. H.R. Sardjono, jika melihat rumusan pada Pasal 66 UU 1/1974 ini, maka UU 1/1974 tidaklah mencabut secara menyeluruh ketentuan-ketentuan yang mengatur tentang perkawinan, melainkan hanya menghapus kekuatan hukum dari ketentuan dan peraturan lain yang terkait dengan perkawinan khususnya yang telah diatur dalam UU $1 / 1974 .{ }^{15}$

UU 1/1974 meletakkan ketentuan tentang perjanjian perkawinan dalam Bab 5 yang hanya diatur dalam 1 (satu) pasal yaitu Pasal 29 yang berisi 4 (empat) ayat. Adapun ketentuan dari pasal tersebut adalah sebagai berikut:

a. Pada waktu atau sebelum perkawinan dilangsungkan, kedua pihak atas persetujuan bersama dapat mengadakan perjanjian tertulis yang disahkan oleh Pegawai Pencatat Perkawinan, setelah mana isinya berlaku juga terhadap pihak ketiga sepanjang pihak ketiga tersangkut.

b. Perjanjian tersebut tidak dapat disahkan bilamana melanggar batas hukum, agama dan kesusilaan.

c. Perjanjian tersebut berlangsung semenjak perkawinan dilangsungkan.

\footnotetext{
${ }^{15}$ Rusdi Malik, (2009), Memahami Undang-Undang Perkawinan, Jakarta: Universitas Trisakti, hlm. 25.
} 
d. Selama perkawinan berlangsung perjanjian tersebut tidak dapat diubah, kecuali bilamana dari kedua belah pihak ada persetujuan untuk mengubah dan perubahan tidak merugikan pihak ketiga.

Sebagaimana diuraikan di atas, ketentuan-ketentuan dalam KUH Perdata terkait perjanjian perkawinan jauh lebih lengkap dibandingkan dengan ketentuan yang ada dalam Pasal 29 UU 1/1974, dimana ayat-ayat dalam Pasal 29 UU 1/1974 tersebut hanya mengatur tentang kapan perjanjian perkawinan itu dibuat, tentang keabsahannya, saat berlakunya, dan tentang dapat tidaknya perjanjian perkawinan itu diubah. Dari ketentuan-ketentuan yang mengatur perjanjian perkawinan di dalam KUH Per dan UU 1/1974 tersebut, apabila diamati lebih lanjut maka akan didapatkan beberapa perbedaan. Adapun perbedaannya adalah sebagai berikut:

a. KUH Perdata mewajibkan perjanjian perkawinan dibuat dengan akta Notaris, sedangkan menurut UU 1/1974 tidak ada ketentuan yang mengharuskan perjanjian perkawinan dibuat dengan akta Notaris. Namun para pihak yang bekepentingan tetap dapat membuat perjanjian perkawinan ke dalam akta Notaris apabila para pihak tersebut menghendakinya;

b. Agar perjanjian perkawinan mengikat pihak ketiga, menurut KUH Perdata perjanjian perkawinan harus dibukukan pada Kepaniteraan Pengadilan Negeri setempat, sedangkan menurut UU 1/1974 perjanjian perkawinan harus disahkan oleh pegawai pencatat perkawinan dimana perkawinan itu dicatatkan;

c. Perjanjian perkawinan menurut KUH Perdata hanya bisa dibuat sebelum perkawinan dilangsungkan, sedangkan menurut UU 1/1974 perjanjian perkawinan dapat dibuat sebelum atau pada saat perkawinan dilangsungkan;

d. Perjanjian perkawinan di dalam KUH Perdata tidak dapat diubah setelah perkawinan dilangsungkan, sedangkan menurut UU 1/1974 perjanjian perkawinan dapat diubah setelah dilangsungkanya perkawinan asalkan ada kesepakatan antara kedua belah pihak serta perubahannya tidak merugikan bagi pihak ketiga.

\section{Perjanjian Perkawinan Pasca Putusan Mahkamah Konstitusi Nomor 69/PUU- XIII/2015}

Putusan Mahkamah Konstitusi Nomor 69/PUU-XIII/2015 berkaitan dengan permohonan Nyonya Ike Farida, seorang Warga Negara Indonesia (WNI) yang melakukan perkawinan dengan seorang Warga Negara Jepang (WNA). Permohonan ini diajukan oleh pemohon dikarenakan ia dan suaminya mengalami permasalahan saat membeli satu unit rumah susun di daerah Jakarta. Akan tetapi setelah dibayar lunas, rumah susun tersebut tidak kunjung diserahkan oleh pengembang, dan bahkan pada akhirnya perjanjian pembelian rumah susun itu pun juga dibatalkan secara 
sepihak oleh pihak pengembang dengan alasan suami pemohon adalah seorang WNA dan pemohon tidak memiliki perjanjian perkawinan.

Pengembang menyatakan bahwa sesuai dengan ketentuan dalam Pasal 36 ayat (1) UUPA dan Pasal 35 ayat (1) UU 1/1974, seorang perempuan yang menikah dengan WNA dilarang membeli tanah dan/atau bangunan dengan Hak Guna Bangunan, atau dengan kata lain tidak boleh memiliki Hak Milik dan Hak Guna Bangunan atas benda tidak bergerak. Oleh karenanya pengembang memutuskan untuk tidak melakukan Perjanjian Pengikatan Jual Beli (PPJB) ataupun Akta Jual Beli (AJB) dengan pemohon karena hal tersebut melanggar Pasal 36 ayat (1) UUPA. Sehingga pemohon merasa bahwa hak konstitusionalnya sebagai warga negara telah dilanggar atau dirampas.

Berdasarkan alasan inilah kemudian pemohon yaitu Nyonya Ike Farida mengajukan permohonan kepada Mahkamah Konstitusi yang pokok permohonannya adalah pengujian konstitusionalitas norma Undang-Undang, yaitu pengujian Pasal 21 ayat (1), ayat (3) dan Pasal 36 ayat (1) Undang-Undang Nomor 5 Tahun 1960 tentang Peraturan Pokok Dasar-Dasar Agraria (yang selanjutnya disebut UUPA), serta Pasal 29 ayat (1), ayat (3), ayat (4) dan Pasal 35 ayat (1) Undang-Undang Nomor 1 Tahun 1974 tentang Perkawinan terhadap UUD 1945. Adapun substansi pasal-pasal dari dua undang-undang yang hendak diuji adalah menyangkut hak-hak warga negara Indonesia yang melakukan perkawinan dengan warga negara asing yang tidak memiliki perjanjian perkawinan pisah harta untuk mempunyai Hak Milik dan Hak Guna Bangunan.

Akhirnya pada tanggal 27 Oktober 2016, Mahkamah Konstitusi mengabulkan sebagian permohonan Nyonya Ike Farida selaku pemohon yang berkaitan dengan pengujian Pasal 29 ayat (1), ayat (3), dan ayat (4) dengan mengeluarkan Putusan Mahkamah Konstitusi Nomor 69/PUU-XIII/2015, serta menolak permohonan pemohon untuk selain dan selebihnya. Adapun amar putusannya adalah sebagai berikut:

a. Pasal 29 ayat (1) Undang-Undang Nomor 1 Tahun 1974 tentang Perkawinan (Lembaran Negara Republik Indonesia Tahun 1974 Nomor 1, Tambahan Lembaran Negara Republik Indonesia Nomor 3019) bertentangan dengan Undang-Undang Dasar Negara Republik Indonesia Tahun 1945 sepanjang tidak dimaknai "Pada waktu, sebelum dilangsungkan atau selama dalam ikatan perkawinan kedua belah pihak atas persetujuan bersama dapat mengajukan perjanjian tertulis yang disahkan oleh pegawai pencatat perkawinan atau notaris, setelah mana isinya berlaku juga terhadap pihak ketiga sepanjang pihak ketiga tersangkut";

b. Pasal 29 ayat (1) Undang-Undang Nomor 1 Tahun 1974 tentang Perkawinan (Lembaran Negara Republik Indonesia Tahun 1974 Nomor 1, Tambahan Lembaran Negara Republik Indonesia Nomor 3019) tidak mempunyai kekuataan hukum mengikat sepanjang tidak dimaknai "Pada 
waktu, sebelum dilangsungkan atau selama dalam ikatan perkawinan kedua belah pihak atas persetujuan bersama dapat mengajukan perjanjian tertulis yang disahkan oleh pegawai pencatat perkawinan atau notaris, setelah mana isinya berlaku juga terhadap pihak ketiga sepanjang pihak ketiga tersangkut";

c. Pasal 29 ayat (3) Undang-Undang Nomor 1 Tahun 1974 tentang Perkawinan (Lembaran Negara Republik Indonesia Tahun 1974 Nomor 1, Tambahan Lembaran Negara Republik Indonesia Nomor 3019) bertentangan dengan Undang-Undang Dasar Negara Republik Indonesia Tahun 1945 sepanjang tidak dimaknai "Perjanjian tersebut mulai berlaku sejak perkawinan dilangsungkan, kecuali ditentukan lain dalam Perjanjian Perkawinan";

d. Pasal 29 ayat (3) Undang-Undang Nomor 1 Tahun 1974 tentang Perkawinan (Lembaran Negara Republik Indonesia Tahun 1974 Nomor 1, Tambahan Lembaran Negara Republik Indonesia Nomor 3019) tidak mempunyai kekuatan hukum mengikat sepanjang tidak dimaknai "Perjanjian tersebut mulai berlaku sejak perkawinan dilangsungkan, kecuali ditentukan lain dalam Perjanjian Perkawinan";

e. Pasal 29 ayat (4) Undang-Undang Nomor 1 Tahun 1974 tentang Perkawinan (Lembaran Negara Republik Indonesia Tahun 1974 Nomor 1, Tambahan Lembaran Negara Republik Indonesia Nomor 3019) bertentangan dengan Undang-Undang Dasar Negara Republik Indonesia Tahun 1945 sepanjang tidak dimaknai "Selama perkawinan berlangsung, perjanjian perkawinan dapat mengenai harta perkawinan atau perjanjian lainnya, tidak dapat diubah atau dicabut, kecuali bila dari kedua belah pihak ada persetujuan untuk mengubah atau mencabut, dan perubahan atau pencabutan itu tidak merugikan pihak ketiga";

f. Pasal 29 ayat (4) Undang-Undang Nomor 1 Tahun 1974 tentang Perkawinan (Lembaran Negara Republik Indonesia Tahun 1974 Nomor 1, Tambahan Lembaran Negara Republik Indonesia Nomor 3019) tidak mempunyai kekuatan hukum mengikat sepanjang tidak dimaknai "Selama perkawinan berlangsung, perjanjian perkawinan dapat mengenai harta perkawinan atau perjanjian lainnya, tidak dapat diubah atau dicabut, kecuali bila dari kedua belah pihak ada persetujuan untuk mengubah atau mencabut, dan perubahan atau pencabutan itu tidak merugikan pihak ketiga".

Dari amar putusan di atas, dapat dilihat adanya perbedaan antara isi ketentuan Pasal 29 UU 1/1974 sebelum dikeluarkannya PMK 69/2015, dimana putusan tersebut telah mengubah dan menambah norma pengaturan perjanjian perkawinan yang sebelumnya diatur dalam Pasal 29 UU 1/1974. Perbedaannya yaitu: 
a. Sebelum adanya PMK 69/2015, perjanjian perkawinan dapat dibuat sebelum atau pada waktu perkawinan dilangsungkan dan disahkan oleh Pegawai Pencatat Perkawinan. Sedangkan setelah adanya PMK 69/2015, perjanjian perkawinan dapat dibuat sebelum, pada waktu dilangsungkan, atau selama dalam ikatan perkawinan dan dapat disahkan oleh Pegawai Pencatat Perkawinan atau oleh Notaris;

b. Sebelum adanya PMK 69/2015, perjanjian perkawinan tersebut mulai berlaku sejak perkawinan dilangsungkan. Sedangkan setelah adanya atau pasca PMK 69/2015, perjanjian perkawinan mulai berlaku sejak perkawinan dilangsungkan, kecuali ditentukan lain dalam perjanjian perkawinan;

c. Sebelum PMK 69/2015, perjanjian perkawinan yang telah dibuat tersebut hanya dapat diubah dengan persetujuan para pihak sepanjang tidak merugikan pihak ketiga. Sedangkan setelah adanya PMK 69/2015, perjanjian perkawinan dapat diubah atau dicabut dengan persetujuan para pihak sepanjang tidak merugikan pihak ketiga.

d. Tanggung Jawab Atas Pelunasan Utang Bersama Sebelum Putusan Mahkamah Konstitusi Nomor 69/PUU-XIII/2015.

\section{Tanggung Jawab Atas Pelunasan Utang Bersama Sebelum Putusan Mahkamah Konstitusi Nomor 69/PUU-XIII/2015}

Perkawinan mengakibatkan adanya suatu ikatan hak dan kewajiban, serta suatu bentuk kehidupan bersama dari pribadi yang melakukan hubungan perkawinan itu, yaitu membentuk suatu keluarga atau somah (gezin atau household). ${ }^{16}$ Salah satu akibat hukum dari suatu perkawinan yang sah adalah terciptanya harta benda perkawinan. Berdasarkan ketentuan dalam KUH Perdata, sejak perkawinan dilangsungkan, maka secara hukum terjadi percampuran harta antara suami dan istri, dengan catatan jika tidak diadakan perjanjian apapun sebelum perkawinan berlangsung. ${ }^{17}$ Hal ini berarti apabila suami istri tidak membuat perjanjian perkawinan sebelum perkawinan dilangsungkan, maka seluruh harta termasuk hadiah dan warisan yang mereka peroleh masing-masing sebelum perkawinan akan menjadi harta bersama. Akan tetapi ketentuan ini dapat disimpangi jika si pewaris atau pemberi hibah menentukan bahwa harta warisan atau hadiah tersebut tetap menjadi milik penerima. Ketentuan ini sebagaimana diatur dalam Pasal 119 KUH Perdata yang isinya sebagai berikut:

"Mulai saat perkawinan dilangsungkan, demi hukum berlakulah persatuan bulat antara harta kekayaan suami dan istri, sekedar mengenai itu dengan perjanjian kawin tidak diadakan ketentuan lain.

Persatuan itu sepanjang perkawinan tak boleh ditiadakan atau diubah dengan sesuatu persetujuan antara suami dan istri."

\footnotetext{
${ }^{16}$ Soerjono Soekanto, (2002), Hukum Adat Indonesia, Jakarta: PT Raja Grafindo Persada, hlm. 244.

${ }^{17}$ Subekti, (1996), Pokok-Pokok Hukum Perdata, Jakarta: PT Intermasa, hlm. 31.
} 
Percampuran harta kekayaan dalam perkawinan sebagaimana diatur dalam KUH Perdata ini meliputi seluruh aktiva dan pasiva, baik yang dibawa oleh masingmasing pihak dalam perkawinan maupun yang akan diperoleh di kemudian hari selama perkawinan. Harta kekayaan bersama ini oleh undang-undang disebut dengan gemeenschap. ${ }^{18}$

Sebagaimana yang diatur dalam Pasal 124 KUH Perdata, hak untuk mengurus harta kekayaan bersama dalam perkawinan tersebut berada di tangan suami, yang dalam hal ini memiliki kekuasaan yang sangat luas. Pengurusan ini meliputi hak untuk menjual, memindahtangankan, dan membebani tanpa campur tangan istrinya. ${ }^{19}$ Atas kekuasaan yang sangat luas ini, kedudukan istri menjadi sangat lemah. Oleh karena itu, undang-undang memberikan beberapa upaya untuk memperkuat kedudukan istri, yakni: ${ }^{20}$

a. Wewenang untuk meminta pemisahan harta kepada Hakim apabila pengurusan yang dilakukan oleh suami sangat buruk, dengan memenuhi syarat-syarat yang diatur dalam Pasal 186 KUH Perdata;

b. Wewenang untuk meminta agar suaminya diletakkan di bawah pengampuan (curatele), dengan memenuhi syarat-syarat yang ditentukan dalam Pasal 434 ayat (3) KUH Perdata; dan

c. Wewenang untuk meminta pelepasan diri atas harta bersama apabila terjadi perceraian, sebagaimana diatur dalam Pasal 132 KUH Perdata. Tindakan ini bertujuan untuk menghindarkan diri dari penagihan utang bersama, baik utang yang telah diperbuat oleh suami maupun oleh si istri itu sendiri. Akan tetapi tetap tidak mungkin untuk menghindarkan diri dari utang pribadi. ${ }^{21}$

UU 1/1974 memiliki konsep yang berbeda dengan ketentuan dalam KUH Perdata tentang harta benda dalam perkawinan. Sebagaimana diatur dalam Pasal 35 UU 1/1974, harta benda dalam perkawinan dibedakan menjadi 2 (dua) yaitu harta bawaan dan harta bersama.

Terkait dengan harta bawaan, baik suami atau istri berhak untuk menggunakan harta bawaannya masing-masing dan juga dapat melakukan perbuatan hukum terhadapnya tanpa persetujuan dari kedua belah pihak. Sebagai dasar hukumnya adalah Pasal 36 ayat (2) UU 1/1974, yang mengatur bahwa, "mengenai harta bawaan masing-masing suami atau istri mempunyai hak sepenuhnya untuk melakukan perbuatan hukum mengenai harta bendanya".

Secara bahasa, harta bersama adalah dua kata yang terdiri dari kata harta dan bersama. Menurut Kamus Besar Bahasa Indonesia (KBBI), harta dapat berarti barang-barang (seperti uang dan sebagainya) yang menjadi kekayaan dan dapat

\footnotetext{
${ }^{18}$ Ibid. hlm. 32.

${ }^{19}$ Komariah, Op. Cit. hlm. 54.

${ }^{20}$ Ibid. hlm. 55.

${ }^{21}$ Subekti, Loc. Cit. hlm. 33.
} 
berarti kekayaan berwujud dan tidak berwujud yang bernilai. Harta bersama berarti harta yang dipergunakan (dimanfaatkan) bersama-sama. ${ }^{22}$

Sayuti Thalib dalam bukunya yang berjudul Hukum Kekeluargaan di Indonesia juga mengatakan bahwa harta bersama adalah harta kekayaan yang diperoleh selama perkawinan diluar hadiah atau warisan, maksudnya adalah harta yang didapat atas usaha mereka atau sendiri-sendiri yaitu suami dan istri selama masa perkawinan.

Kemudian Prof. Abdul Kadir Muhammad, S.H. dalam bukunya yang berjudul Hukum Harta Kekayaan menyatakan bahwa: ${ }^{23}$

Konsep harta bersama yang merupakan harta kekayaan dapat ditinjau dari segi ekonomi dan dari segi hukum, walaupun kedua segi tinjauan itu berbeda, keduanya ada hubungan satu sama lain. Tinjauan dari segi ekonomi menitikberatkan pada nilai kegunaan, sebaliknya tinjauan dari segi hukum menitikberatkan pada aturan hukum yang mengatur.

Menurut Drs. H. Abdul Manan, S.H., S.IP., M.Hum, bahwa "harta bersama adalah harta yang diperoleh selama ikatan perkawinan berlangsung dan tanpa mempersoalkan terdaftar atas nama siapa." 24

Harta perkawinan akan menjadi harta bersama jika tidak ada perjanjian mengenai status harta tersebut sebelum ada pada saat perkawinan dilangsungkan, kecuali harta tersebut diperoleh dari hadiah atau warisan atau bawaan masing-masing suami istri yang dimiliki sebelum perkawinan sebagaimana dijelaskan pada pasal 35 ayat (2) UU $1 / 1974 .^{25}$

Sebagaimana telah diuraikan sebelumnya di atas, bahwa harta bersama dalam perkawinan adalah meliputi seluruh aktiva dan pasiva, atau yang dalam hal ini disebut dengan utang. Terkait dengan utang itu sendiri, Prof. Subekti, S.H. membedakan utang menjadi 2 (dua), yaitu utang pribadi dan utang bersama.

Utang pribadi adalah utang yang melekat pada milik pribadi dari masingmasing suami dan istri, yaitu di dalam hal barang yang diberikan dengan ketentuan tidak boleh masuk dalam percampuran harta. Terjadinya utang pribadi ini dalam perkawinan dapat berupa pengeluaran atau utang yang diperuntukan untuk harta dari hasil warisan atau hibah. ${ }^{26}$ Utang pribadi dibayar dari harta kekayaan pribadi dan juga dari harta bersama, karena suami maupun istri mempunyai setengah bagian dari harta bersama dan tidaklah mungkin dapat dipecah begitu saja. Jika utang pribadi tersebut merupakan utang yang timbul sebelum perkawinan, maka harta bersama

\footnotetext{
${ }^{22}$ Pusat Pembinaan dan Pengembangan Bahasa Departemen Pendidikan dan Kebudayaan, (1995), Kamus Besar Bahasa Indonesia, Edisi Kedua, Jakarta: Balai Pustaka, hlm. 342.

${ }^{23}$ Abdul Kadir Muhammad, (1994), Hukum Harta Kekayaan, Bandung: PT Citra Aditya Bakti, hlm. 9.

${ }^{24}$ Abdul Manan, (1997), Beberapa Masalah tentang Harta Bersama, Mimbar Hukum, Nomor 33, Tahun VIII, hlm. 59.

${ }^{25}$ H.A. Damanhuri HR, Op. Cit. Hlm. 29.

${ }^{26}$ Julius Martin Saragih, (2017), Pertanggungjawaban Hutang-Hutang Persatuan Setelah Putusnya Perkawinan, Diponegoro Law Journal, Volume 6, Nomor 1, Semarang: Fakultas Hukum Universitas Diponegoro, hlm. 8.
} 
tidak dapat digunakan untuk membayar utang tersebut dan harus diambil dari harta pribadi suami atau istri yang berutang. Untuk suatu utang pribadi, harus dituntut suami atau istri yang membuat utang tersebut, sedangkan yang harus disita terlebih dahulu adalah benda milik pribadi. Namun apabila tidak ada benda milik pribadi atau ada tetapi tidak mencukupi untuk melunasi utang tersebut, maka dapat menyita benda yang merupakan harta bersama. Akan tetapi, jika suami yang berutang, benda pribadi milik istri tidak dapat disita, begitu pula sebaliknya. ${ }^{27}$

Terjadinya utang piutang dalam perkawinan tidak lepas dari adanya usaha untuk pemenuhan kebutuhan dalam perkawinan, sehingga tentu akan menjadi persoalan ketika utang tersebut lalai dalam penyelesaiaannya. Perkawinan erat hubungannya dengan harta dan utang dikarenakan kehidupan suatu rumah tangga secara langsung pasti bersentuhan dengan penghasilan dan pengeluaran yang sering menjadi sumber permasalahan dalam kedudukannya. Terjadinya utang-utang dalam perkawinan dapat dikategorikan menjadi beban bersama, karena utang dalam perkawinan adalah utang-utang yang dipergunakan untuk kepentingan bersama dan atas kesepakatan bersama, sehingga menjadi beban dan tanggung jawab bersama antara suami dan istri. ${ }^{28}$

Utang dalam perkawinan yang membebani harta bersama dapat terjadi karena beberapa hal, yaitu: ${ }^{29}$

a. Adanya utang sebelum perkawinan. Dalam hal ini terkait dengan Pasal 35 ayat (2) UU 1/1974, bahwa harta yang dimiliki masing-masing suami dan istri sebelum perkawinan, adalah menjadi harta milik pribadi masing-masing pihak. Apabila adanya hutang baik suami atau istri yang dilakukan sebelum perkawinan dan dibawa ke dalam perkawinan yang telah berlangsung, maka masing-masing pihaklah yang bertanggung jawab melunasinya;

b. Utang untuk keperluan rumah tangga. Utang ini diperuntukan untuk pengeluaran sandang, papan, pangan yang dilakukan suami maupun istri dalam memenuhi kebutuhan rumah tangga;

c. Terdapat pengeluaran utang-utang untuk kepentingan usaha;

d. Melakukan ganti rugi karena salah satu pihak melakukan perbuatan melawan hukum;

e. Adanya denda-denda; dan

f. Adanya utang warisan/hibah yang masuk ke dalam persatuan.

Untuk mengerti bagaimana terjadinya utang bersama dalam perkawinan, terlebih dahulu perlu diteliti apakah perkawinan tersebut menggunakan perjanjian perkawinan atau tidak. Ada atau tidaknya perjanjian perkawinan akan menjadi penentu bagaimana seharusnya pengaturan harta maupun utang yang akan

\footnotetext{
${ }^{27}$ Subekti, Op. Cit. hlm. 34.

${ }^{28}$ Ibid. hlm. 5.

${ }^{29}$ Ibid. hlm. 6.
} 
diberlakukan dalam perkawinan. Jika dalam perkawinan tidak dibuat perjanjian perkawinan, maka secara otomatis seluruh harta akan menjadi persatuan baik yang terjadi selama perkawinan maupun harta masing-masing yang dibawa ke dalam perkawinan. Dalam percampuran harta terdapat aktiva dan pasiva di dalamnya. Jika tidak ada perjanjian perkawinan, maka secara otomatis terjadi persatuan untung dan rugi. Selain itu juga disebutkan dalam Pasal 120 KUH Perdata yaitu:

Sekedar mengenai laba-labanya, persatuan itu meliputi harta kekayaan suami daa istri, bergerak dan tak bergerak, baik yang sekarang, maupun yang kemudian, maupun pula, yang mereka peroleh dengan cumacuma, kecuali dalam hal terakhir ini si yang mewariskan atau yang menghibahkan dengan tegas menentukan sebaliknya.

Kemudian untuk beban-bebannya, percampuran harta juga meliputi segala utang suami istri masing-masing yang terjadi baik sebelum maupun selama perkawinan. Percampuran harta benda tidak hanya terdiri dari barang-barang harta kekayaan (aktiva), melainkan juga terdiri dari beban-beban dan utang-utang atau pasiva yang artinya jika selama perkawinan diperoleh harta benda dalam jumlah tertentu maka hal itu menjadi kekayaan (aktiva) rumah tangga, sedang jika terjadi utang selama perkawinan, maka utang-utang tersebut menjadi beban utang rumah tangga. ${ }^{30}$ Selain itu dalam percampuran harta juga terdapat pasiva atau beban-beban dan utang. Segala beban-beban dan utang yang dilakukan suami atau istri sebelum dan sepanjang perkawinan akan menjadi beban harta persatuan kecuali untuk utang kematian karena terdapat ketentuan lain di dalamnya. ${ }^{31}$

Utang dapat terjadi dalam percampuran harta karena pada dasarnya utangutang yang terjadi adalah untuk kesejahteraan rumah tangga bersama. Hal inilah yang termasuk kepada beban dalam persatuan yaitu meliputi utang, baik yang dibuat sebelum maupun sesudah perkawinan, kemudian terdapat juga beban ahli waris yang menjadi tanggung jawab ahli waris, dalam hal ini jika suami dan istri merupakan ahli waris yang dibebankan tersebut dan masuk ke dalam perkawinan. Namun terhadap percampuran harta ini terdapat pengecualian bahwa harta tersebut bukan harta bersama apabila terdapat perjanjian perkawinan, ada hibah atau warisan yang ditetapkan oleh pewaris. ${ }^{32}$

Kemudian terkait dengan pelunasan atas utang bersama, pertama-tama yang dapat disita adalah benda dalam harta bersama. Apabila tidak mencukupi, maka dapat menyita benda milik pribadi dari suami atau istri yang membuat utang tersebut. Jika utang bersama dibuat oleh istri, maka suami selalu dapat diminta

\footnotetext{
${ }^{30}$ Andy Hartanto, (2012), Hukum Harta Kekayaan Perkawinan (Menurut Burgerlijk Wetboek dan UndangUndang Perkawinan), Yogyakarta: Lakatitbang, hlm. 37.

${ }^{31}$ Julius Martin Saragih, Op. Cit. hlm. 7.

${ }^{32}$ Julius Martin Saragih, Loc. Cit.
} 
pertanggungjawaban atas utang-utang bersama tersebut, tetapi istri tidak dapat diminta pertanggungjawaban atas utang-utang bersama yang dibuat oleh suami. ${ }^{33}$

Sekalipun telah diatur dengan jelas dalam undang-undang, permasalahan tentang harta bersama masih saja sering terjadi, misalnya adalah penghapusan atau pembubaran percampuran harta kekayaan dalam perkawinan. Pasal $126 \mathrm{KUH}$ Perdata menyebutkan alasan-alasan yang menyebabkan pembubaran percampuran kekayaan, yaitu:

a. Karena kematian;

b. Karena berlangsungnya suatu perkawinan atas izin Hakim, setelah adanya keadaan tidak hadir si suami;

c. Karena perceraian;

d. Karena perpisahan tentang meja dan ranjang;

e. Karena perpisahan harta benda, meskipun perkawinan masih utuh.

Setelah suatu perkawinan berakhir, maka diadakan pembagian harta bersama. Dengan demikian, hak pengurusan suami terhadap harta tersebut dihentikan sejak berakhirnya perkawinan. Hal ini juga berarti bubarnya percampuran harta. Menurut Pasal 128 KUH Perdata, setelah bubarnya percampuran harta, maka harta bersama dibagi dua antara suami dan istri atau antara para ahli waris mereka masing-masing dengan tidak memedulikan soal dari pihak manakah harta tersebut diperolehnya. Sebagaimana diatur dalam Pasal 130 KUH Perdata, bahwa setelah bubarnya percampuran harta, suami boleh ditagih karena utang-utang bersama seluruhnya, tetapi suami berhak menuntut kembali setengah bagian dari utang-utang itu kepada istri atau kepada para ahli warisnya. ${ }^{34}$

Meskipun undang-undang telah mengatur mengenai berbagai ketentuan terkait harta bersama, undang-undang dalam hal ini KUH Perdata dan UU 1/1974 juga memberikan peluang bagi pasangan suami istri untuk melakukan pemisahan harta dalam perkawinan berupa kesepakatan atau persetujuan bersama yang dituangkan dalam bentuk perjanjian perkawinan.

Menurut ketentuan dalam KUH Perdata, calon pasangan suami istri bebas menentukan isi perjanjian perkawinan yang akan mereka buat. Namun dalam menentukan isi perjanjian perkawinannya dibatasi oleh ketentuan-ketentuan sebagai berikut: ${ }^{35}$

a. Perjanjian yang dibuat tidak bertentangan dengan kesusilaan dan

ketertiban umum;

b. Perjanjian yang dibuat tidak boleh menyimpang dari:

1) Hak-hak yang timbul dari kekuasaan suami, misalnya hak menentukan domisili.

2) Hak-hak yang timbul dari kekuasaan orang tua misalnya hak mendidik anak-anaknya.

\footnotetext{
${ }^{33}$ Subekti, Loc. Cit.

${ }^{34}$ Komariah, Op. Cit. hlm. 56.

${ }^{35}$ Ibid. hlm. 57.
} 
3) Hak-hak yang ditentukan oleh undang-undang bagi mempelai yang hidup terlama, misalnya hak menjadi wali.

c. Tidak diperbolehkan membuat perjanjian yang mengandung pelepasan hak atas harta peninggalan orang-orang yang menurunkannya;

d. Tidak diperbolehkan membuat perjanjian bahwa salah satu pihak akan memikul utang dari pada bagiannya dalam aktiva;

e. Tidak diperbolehkan membuat perjanjian dengan kata-kata umum yang mengatakan bahwa kedudukan mereka akan diatur oleh undang-undang negara asing dan peraturan yang pernah berlaku di Indonesia atau di Belanda.

UU 1/1974 tidak mengatur secara spesifik mengenai hal-hal yang dilarang di dalam suatu perjanjian perkawinan seperti layaknya yang diatur dalam KUH Perdata. UU 1/1974 hanya mengatur bahwa perjanjian perkawinan tidak boleh melanggar batas-batas hukum, agama dan kesusilaan, seperti yang diatur dalam Pasal 29 ayat (2) UU $1 / 1974$.

\section{Tanggung Jawab Atas Pelunasan Utang Bersama Pasca Putusan Mahkamah Konstitusi Nomor 69/PUU-XIII/2015}

Pasca dikeluarkannya PMK 69/2015, perjanjian perkawinan dapat dibuat sebelum, pada saat atau selama dalam masa perkawinan. Berbeda dengan UU 1/1974 yang menghendaki perjanjian perkawinan hanya dapat dibuat sebelum atau pada saat perkawinan dilangsungkan. Hal ini tentu menimbulkan berbagai permasalahan baru terkait pembuatan perjanjian perkawinan. Salah satunya adalah penyelesaian permasalahan utang-utang bersama dalam suatu perkawinan.

Jika melihat PMK 69/2015 ini membuka peluang baru bagi pasangan suami istri untuk membuat perjanjian perkawinan dalam masa ikatan perkawinan atau setelah perkawinan berlangsung, tidak menutup kemungkinan akan ada pihak-pihak yang dirugikan khususnya apabila suami atau istri ingin memanfaatkan peluang yang ada, terlebih lagi jika dalam pembuatannya didasari dengan niatan atau itikad buruk oleh salah satu pihak demi memenuhi kepentingan pribadinya. Secara umum, bentuk-bentuk perjanjian perkawinan meliputi:

a. Pemisahan harta perkawinan

Pasal 119 KUH Perdata menyatakan bahwa semanjak dilangsungkannya perkawinan, maka berlakulah bulat persatuan harta antara suami dan istri. Untuk meniadakan persatuan harta dalam perkawinan tersebut maka dibuatlah perjanjian perkawinan.

b. Persatuan untung rugi

Maksud dari persatuan untung rugi dalam perjanjian perkawinan adalah agar masing-masing pihak akan tetap mempertahankan milik mereka, baik berupa harta bawaan atau hadiah yang diperuntukan kepada masing- 
masing suami istri beserta hak-hak yang diberikan oleh Undang-Undang. Sedangkan semua penghasilan yang diperoleh selama masa perkawinan menjadi hak bersama begitu pula dengan kerugian yang diderita selama masa perkawinan menjadi beban bersama. ${ }^{36}$

c. Persatuan hasil pendapatan

Yang dimaksud persatuan hasil pendapatan adalah keuntungan yang didapat selama perkawinan berlangsung merupakan hak dari suami istri tetapi tidak untuk kerugian yang diderita selama masa perkawinan tidak diperjanjiakan atau tetap menjadi beban masing-masing pihak. Berkaitan dengan hal ini, Wirdjono Prodjodikoro berpendapat bahwa istri hanya bertanggung jawab atas kerugian yang diderita akibat perbuatannya sendiri. ${ }^{37}$

Suami istri yang melakukan suatu perbuatan hukum dengan pihak ketiga dalam hal ini utang bersama yang dilakukan dalam ikatan perkawinan, memiliki kewajiban untuk melunasi segala kewajibannya yang didasarkan pada tanggung jawab moral sesuai dengan janjinya yang telah disepakati dalam perjanjian. ${ }^{38}$ Pada dasarnya, pertanggungjawaban terhadap utang bersama dalam perkawinan adalah tergantung kepada hukum yang mengaturnya. Dalam hal pemisahan harta terdapat juga pembagian beban-beban seperti utang di dalamnya. Kewajiban pelunasan utang bersama berkaitan dengan hubungan intern antara suami atau istri yang mengarah pada siapakah yang harus memikul pelunasan utang itu atau bagian siapakah yang harus dikurangi untuk melunasi utang tersebut. ${ }^{39}$ Sedangkan dalam perjanjian perkawinan persatuan hasil dan pendapatan, semua harta perkawinan menjadi harta bersama. Sehingga ada kerja sama antara suami dan istri dalam menyelesaikan permasalahan utang.

Peraturan mengenai pelunasan dan pertanggungjawaban terhadap utang-utang yang lahir dari suami dan istri, baik sebelum perkawinan maupun selama perkawinan berlangsung tidak diatur dalam UU 1/1974, demikian pula tidak ada pasal-pasal yang khusus mengatur mengenai tanggung jawab atas utang pribadi maupun utang bersama. $^{40}$

Dengan demikian dalam UU 1/1974, masalah tanggung jawab suami istri terkait pelunasan utang harus dibedakan juga ke dalam tanggung jawab intern antara suami dan istri serta tanggung jawab extern terhadap pihak ketiga atau kreditur. Sehingga suami maupun istri bertanggung jawab sendiri atas utang-utang pribadinya. Karena harta bersama merupakan hasil usaha dan pendapatan suami istri sepanjang

\footnotetext{
${ }^{36}$ H. A. Damanhuri HR, Op. Cit. hlm. 15.

${ }^{37}$ H. A. Damanhuri HR, Loc.Cit.

${ }^{38}$ Sonny Dewi Judiasih, (2015), Harta Benda Perkawinan Kajian Terhadap Kesetaraan Hak dan Kedudukan Suami dan Istri Atas Kepemilikan Harta Dalam Perkawinan, Bandung: PT Refika Aditama, hlm. 91.

${ }^{39}$ Julius Martin Saragih, Op. Cit. hlm. 9.

${ }^{40}$ Ibid. hlm. 10
} 
perkawinan, maka atas utang bersama layaklah jika suami dan istri masing-masing memikul setengah dari utang bersama. ${ }^{41}$

Kemudian pasca PMK 69/2015 yang mengatur bahwa perjanjian perkawinan dapat dibuat sebelum, pada saat, atau selama dalam masa ikatan perkawinan, terkait pelunasan utang bersama yang timbul sebelum adanya perjanjian perkawinan tersebut pelunasannya dapat diperjanjikan sesuai kesepakatan kedua pihak yaitu suami dan istri. Hal ini karena tidak ada aturan yang melarang adanya klausula tersebut untuk dituangkan dalam perjanjian perkawinan. Namun jika dengan adanya perjanjian perkawinan yang di dalamnya mengatur mengenai pelunasan utang bersama tersebut justru berakibat merugikan pihak ketiga maka perjanjian perkawinan itu tidak diperbolehkan, sebagaimana yang diatur dalam Pasal 29 ayat (4) UU $1 / 1974$.

\section{E. PENUTUP}

\section{Kesimpulan}

Berdasarkan ketentuan dalam KUH Perdata, dengan adanya suatu perkawinan maka terjadilah percampuran harta antara suami istri, dimana percampuran harta tersebut meliputi seluruh aktiva dan pasiva. Sehingga ketika terjadi pemisahan harta maka pelunasan utang bersama akan dibebankan pada harta bersama. Sedangkan Undang-Undang Nomor 1 Tahun 1974 tentang Perkawinan memisahkan harta bersama dan harta pribadi, yang kemudian juga memisahkan adanya utang bersama dan utang pribadi. Utang pribadi akan dibebankan pada harta pribadi suami dan istri yang melakukan utang tersebut, sedangkan utang bersama merupakan beban bersama suami istri yang harus dipertanggungjawabkan secara bersama-sama. Kemudian pasca Putusan Mahkamah Konstitusi Nomor 69/PUU-XIII/2015, yang mengatur bahwa perjanjian perkawinan dapat dibuat selama dalam masa ikatan perkawinan, terkait tanggung jawab pelunasan utang bersama yang timbul sebelum adanya perjanjian perkawinan tersebut, pelunasannya dapat diperjanjikan sesuai kesepakatan kedua pihak yaitu suami dan istri. Hal ini karena tidak ada aturan yang melarang adanya klausula tersebut untuk dituangkan dalam perjanjian perkawinan. Namun jika dengan adanya perjanjian perkawinan yang di dalamnya mengatur mengenai pelunasan utang bersama tersebut justru berakibat merugikan pihak ketiga maka perjanjian perkawinan itu tidak diperbolehkan, sebagaimana yang diatur dalam Pasal 29 ayat (4) UU 1/1974.

\section{Saran}

Bagi Pemerintah sebagai pihak yang berwenang dalam membuat peraturan perundang-undangan, sebaiknya segera membuat peraturan pelaksana dari Putusan Mahkamah Konstitusi Nomor 69/PUU-XIII/2015 terkait dengan pembuatan perjanjian perkawinan dalam masa ikatan perkawinan yang berakibat terhadap penyelesaian

\footnotetext{
${ }^{41}$ Ibid. hlm. 11
} 
utang bersama. Hal tersebut bertujuan untuk melindungi kepentingan para pihak yang terkait khususnya pihak ketiga.

Bagi masyarakat, agar lebih berhati-hati dalam membuat dan menentukan isi perjanjian perkawinan yang dibuat selama dalam masa ikatan perkawinan. Sehingga nantinya perjanjian perkawinan tersebut tidak merugikan para pihak yang berkaitan di dalamnya terutama pihak ketiga dalam hal ini kreditur maupun bagi Notaris sebagai pihak yang membuat perjanjian perkawinan. Selain itu, bagi para pihak yaitu pasangan suami istri yang membuat perjanjian perkawinan, supaya tidak memanfaatkan celah hukum dari adanya PMK 69/2015 tersebut demi kepentingan pribadinya, misalnya agar dapat lepas dari tanggung jawab pelunasan utang bersama.

\section{DAFTAR PUSTAKA}

\section{Buku :}

Abdul Kadir Muhammad, (1994), Hukum Harta Kekayaan, Bandung: PT Citra Aditya Bakti. Abdul Manan, (1997), Beberapa Masalah tentang Harta Bersama, Mimbar Hukum, Nomor 33, Tahun VIII.

Andy Hartanto, (2012), Hukum Harta Kekayaan Perkawinan (Menurut Burgerlijk Wetboek dan UndangUndang Perkawinan), Yogyakarta: Lakatitbang.

Bambang Waluyo, (1996), Metode Penelitian Hukum, Jakarta: Sinar Grafika.

H.A. Damanhuri HR, (2007), Segi-Segi Hukum Perjanjian Perkawinan Harta Bersama, Bandung: Mandar Maju.

Hilman Hadikusuma, (1990), Hukum Perkawinan Indonesia, Bandung: Mandar Maju.

J. Satrio, (1993), Hukum Harta Perkawinan, Bandung: Citra Aditya Bhakti.

Khomariah, (2004), Hukum Perdata, Malang: UMM Press.

Pusat Pembinaan dan Pengembangan Bahasa Departemen Pendidikan dan Kebudayaan, (1995), Kamus Besar Bahasa Indonesia, Edisi Kedua, Jakarta: Balai Pustaka.

R. Soetojo Prawirohamidjojo dan Asis Safioedin, (1985), Hukum Orang dan Keluarga, Bandung: Alumni.

Rusdi Malik, (2009), Memahami Undang-Undang Perkawinan, Jakarta: Universitas Trisakti. Soerjono Soekanto, (2002), Hukum Adat Indonesia, Jakarta: PT Raja Grafindo Persada.

Sonny Dewi Judiasih, (2015), Harta Benda Perkawinan Kajian Terhadap Kesetaraan Hak dan Kedudukan Suami dan Istri Atas Kepemilikan Harta Dalam Perkawinan, Bandung: PT Refika Aditama.

Subekti, (1996), Pokok-Pokok Hukum Perdata, Jakarta: PT Intermasa.

Wahyono Darmabrata, (2008), Tinjauan Undang-Undang No. 1 Tahun 1974 Tentang Perkawinan beserta Undang-Undang dan Peraturan Pelaksanaannya, Jakarta: Rizkita.

Wirjono Prodjodikoro, (1981), Hukum Perkawinan di Indonesia, Cet. Keenam, Bandung: Sumur Bandung.

\section{Jurnal :}

Annisa Istrianty, (2015), Akibat Hukum Perjanjian Perkawinan Yang dibuat Setelah Perkawinan Berlangsung, Privat Law, Volume 3, Surakarta: Fakultas Hukum Universitas Sebelas Maret. 
Julius Martin Saragih, (2017), Pertanggungjawaban Hutang-Hutang Persatuan Setelah Putusnya Perkawinan, Diponegoro Law Journal, Volume 6, Nomor 1, Semarang: Fakultas Hukum Universitas Diponegoro.

\section{Peraturan Perundang-undangan :}

Kitab Undang-Undang Hukum Perdata Indonesia

Undang-Undang Nomor 1 Tahun 1974 tentang Perkawinan

Undang-Undang Nomor 30 Tahun 2004 tentang Peraturan Jabatan Notaris

Undang-Undang Nomor 2 Tahun 2014 tentang Perubahan Atas Undang-Undang Nomor 30 Tahun 2004 tentang Peraturan Jabatan Notaris

Peraturan Pemerintah Nomor 9 Tahun 1975 tentang Pelaksanaan Undang-Undang Nomor 1 Tahun 1974 tentang Perkawinan

Putusan Mahkamah Konstitusi Nomor 69/PUU-XIII/2015 